\title{
IMPLEMENTASI MANAJEMEN PEMBIAYAAN PENDIDIKAN \\ (STUDY KASUS MTS DARUL KHAIR MASING, KEC. BATUI, KAB. BANGGAI, SULAWESI TENGAH)
}

\author{
Nur Gamar \\ Institut Agama Islam Negeri Sultan Amai Gorontalo
}

\begin{abstract}
Abstrak
Penelitian ini bertujuan untuk mendeskripsikan: (1) sumber-sumber pembiayaan pendidikan MTs Darul Khair Masing Luwuk Banggai; (2) prosedur Manajemen anggaran pendapatan pembiayaan pendidikan MTs Darul Khair Masing Luwuk Banggai; (3) penggunaan anggaran belanja pembiayaan pendidikan MTs Darul Khair Masing Luwuk Banggai; (4) Pertanggungjawaban pembiayaan pendidikan MTs Darul Khair Masing Luwuk Banggai ; dan (5) Pengawasan pembiayaan pendidikan TK An-Nur Luwuk Rajawali Banggai. Metode yang digunakan dalam penelitian ini adalah metode kualitatif dengan teknik pengumpulan data menggunakan wawancara, observasi, dan dokumentasi. Teknik analisis data yang digunakan adalah analisis kualitatif, yaitu proses data, penyajian data, dan kesimpulan awal. Hasil penelitian ini menunjukan bahwa: (1) Sumber-sumber pembiayaan pendidikan bersumber dari masyarakat umum, orang tua santri, dan donator tetap, (2) prosedur Manajemen anggaran pendapatan pembiayaan pendidikan sudah dibuat dalam bentuk program pencapaian anggaran pendapatan. Program-program tersebut berdasarkan jangka waktu yang telah ditetapkan, yaitu: Manajemen anggaran pendapatan pembiayaan jangka pendek dan menengah; (3) penggunaan anggaran belanja pembiayaan pendidikan disesuaikan dengan manajemen awal yang telah dibuat dan disepakati bersama dengan berdasarkan panduan atau patokan yang ada; (4) pertanggungjawaban pembiayaan pendidikanm MTs Darul Khair Masing Luwuk Banggai sudah sesuai dengan manajemen dan dilaksanakan pada akhir tahun. Pelaku penanggungjawab penggunaan anggaran pembiayaan di tersebut adalah bendahara selaku koordinator keuangan; dan (5) dan pengawasan pembiayaan pendidikan MTs Darul Khair Masing Luwuk Banggai ditugaskan pada tim khusus yang bertugas mengawasi dan mengotrol keuangan. Tim yang terlibat dalam pengawas anggaran adalah masyarakat selaku orang tua santri, humas, stakeholders pondok, dan pembina santri.
\end{abstract}

Kata Kunci: manajemen, pembiayaan, pendidikan 


\section{PENDAHULUAN}

Menajemen pembiayaan MTs Darul Khair Masing tidak terlepas pada dinamika laju perkembangan pendidikan Nasional yang terus berkompetisi dengan kegiatan pendidikan yang diselenggarakan oleh swasta maupun keleompok tertentu. Mendesaknya usaha pembaharuan manajemen kususnya mengenai manajemen pembiayaannya antara yang satu dengan yang lainnya kadang berbeda cara dan karakter dalam mengembangkan dirinya sendiri. Hal memang lumrah kondisi lembaga berbeda-beda.

Identitas yang pada perkembangnnya merupakan sebuah lembaga pendidikan dan penyiaran agama Islam, kini orientasi itu lebih berkembang dan dengan tidak keluar dari prinsip kemandirian dan Independensi kepemimpinannya tetap memiliki fungsi : Pertama, sebagai lembaga pendidikan yang melakukan transformasi ilmu Pengetahuan agama Islam dan Nilai-nilai Islaman. Kedua, Sebagai lembaga keagamaan yang melakukan control social (Social Control), dan Ketiga, sebagai lembaga keagamaan yang melakukan rekayasa social (Social Engineering). MTs Darul Khair Masing semakin menyadari perlunya reintegrasi kehidupan dalam MTs Darul Khair Masing dengan erealitas di luarnya, namun demikian tidak sedikit yang dengan pola lamanya dengan menolak segala hal yang berbau barat. Bertahannya dengan system salafi dapat dijadikan contoh fenomena ini, sebaiknya dipihak lain munculnya sejumlah MTs Darul Khair Masing dengan label dan simbol-simbol yang tampak modern menjadi contoh lain kuatnya pengaruh pendidikan Barat yang diusung para para pembaharu bagi dunia MTs Darul Khair Masing.

Terlepas dari pengelolaanya dalam sistem pendidikan nasional merupakan mata rantai yang sangat penting, hal ini tidak hanya kemunculannya yang relative lama tetapi juga karena telah secara signifikan ikut andil dalam upaya mencerdaskan bangsa. Namun disadari atau tidak pondok pesantern semakin sulit dan berat dalam melaksanakan tugas dan fungsi karena mengalami kendala dalam permasalah dalam manajemen pembiayan, baik mengenai subyek maupun obyeknya.

Realitas menujukkan bahwa banyak skandal dengan masalah keuangan dan pembiayaan selalu menjadi kendala dalam melakukan aktivitas pendidikan. Kompleksifitas permasalahan pembiayaan meliputi anggaran, akutantansi, penataan administrasi, alokasi serta kebutuhan pengembangan MTs Darul Khair Masing. MTs Darul Khair Masing memiliki sumber daya baik manusia maupun alamnya namun tidak tertata rapi tidak bisa survive, dan tidak sedikit pula proses pendidikan MTs Darul Khair Masing berjalan lambat karena kesalahan dalam penataan manejemen keuangannya.

Pembiayaan merupakan salah satu komponen penting yang tidak bisa dipisahkan dari penyelenggaraan pendidikan. Setiap upaya pencapaian tujuan pendidikan sangat bergantung pada ketersediaan dan dukungan dana yang memadai. Proses pendidikan pada suatu satuan pendidikan, seperti Madasah dan tidak akan dapat terlaksana tampa dukungan dan ketersediaan pembiayaan yang berkelanjutan dan memadai.

Biaya pendidikan sebenarnya memiliki cakupan yang sangat luas, meliputi semua pengeluaran yang berkenaan dengan penyelenggaraan pendidikan. Dalam konsep pembiayaan pendidikan, sedikitnya ada tiga pertanyaan yang terkait di dalamnya, seperti 
yang diungkapkan oleh Jhones (2007:20) ${ }^{1}$ yaitu bagaimana uang diperoleh untuk membiayai lembaga pendidikan, darimana sumbernya, dan untuk apa/siapa dibelanjakan. sebagai lembaga pendidikan memiliki keunikan seperti infrastruktur yang tidak memadai, keterbatasan dana tetapi proses belajarnya sangatlah efektif dan pondok tersebut memiliki ciri khas yang berbeda dari penggalian sumber keuangannya, sistem dan mekanisme pengelolaan keuangan, pertanggungjawaban keuangan, investasinya, divestasi anggaran, keterkaitan sumber-sumber dana yang diperoleh dengan MTs Darul Khair Masing difusi teknologi dalam pengelolaan keuangan serta posisi kyai dalam kegiatan keuangan.

Dinamika pengelolaan pembiayaan juga tidak dapat dihindari di MTs Darul Khair Masing Luwuk Banggai. Walaupun tidak memiliki sumber anggaran yang besar dan pasti akan tetapi mampu menjalankan fungsinya sebagai suatu lembaga pendidikan terbukti dengan prestasi yang diperoleh santri yang belajar dalam MTs Darul Khair Masing.

Dinamisasi pembiayaan pendidikan itu terjadi pada fungsi manajemen keuangan MTs Darul Khair Masing sebagai obyek Penelitian telah memberi kontribusi besar dalam mencerdaskan kehidupan Bangsa khususnya masyarakat Kecamatan Luwuk maupun kecamatan Tetangga seperti Kecamatan Luwuk Timur Kecamatan Kintom dan Kecamatan Batui

\section{Fokus Penelitian}

Berdasarkan latar belakang masalah yang telah diuraikan sebelumnya, maka penelitian ini difokuskan pada :

1. Apa saja yang menjadi sumber-sumber pembiayaan Pendidikan MTs Darul Khair Masing Luwuk Banggai .

2. Bagaimana manajemen Anggaran Pendapatan Pembiayaan Pendidikan MTs Darul Khair Masing Luwuk Banggai .

3. Bagaimana penggunaan anggaran belanja pembiayaan pendidikan MTs Darul Khair Masing Luwuk Banggai .

4. Bagaimana pertanggungjawaban pembiayaan pendidikan ondok MTs Darul Khair Masing MTs Darul Khair Masing Luwuk Banggai .

5. Bagaimana pengawasan pembiayaan pendidikan MTs Darul Khair Masing Luwuk Banggai

\section{KAJIAN TEORI}

\section{Pengertian Manajemen}

Menurut Kamus Besar Bahasa Indonesia (2008: 870), ${ }^{2}$ manajemen adalah penggunaan sumber daya secara efektif untuk mencapai sasaran. Manajemen pembiayaan pendidikan dimaksudkan sebagai suatu manajemen terhadap fungsi-fungsi keuangan. Menurut George R. Terry (dalam Mulyono, 2008: 16) ${ }^{3}$ menyatakan bahwa manajemen merupakan sebuah proses yang khas, yang berdiri terdiri dari tindakan-tindakan: perencanaan, pengorganisasian, penggantian, dan pengawasan yang dilakukan untuk $\mathrm{m}$

\footnotetext{
${ }^{1}$ Jones T.. School Finance: Technique and Social Policy (London: Collier Macmillan
} Pub. 2007). hlm 10.

\footnotetext{
${ }^{2}$ Kamus besar bahasa Indonesia (2008; Hal 870)

${ }^{3}$ Mulyono (Manajemen kependidikan, Yokyakarta: Hal 16)
} 
enentukan serta mencapai sasaran-sasaran yang telah ditetapkan melalui pemanfaatan sumber daya manusia lain.

Menurut jhonson (dalam Pidarta, 2004:3), ${ }^{4}$ menyatakan bahwa manajemen ialah proses mengintegrasikan sumber-sumber yang tidak berhubungan menjadi system total untuk menyelesaiakan suatu tujuan. Dimana yang dimaksud sebagai sumber mencakup orang, alat, media dan bahan-bahan, uang dan sarana. Semua diarahkan dan dikoordinasikan agar terpusat dalam rangka menyelesaikan tujuan.

Manajemen yang baik adalah manajemen yang tidak jauh menyimpang dari konesp, dan sesuai dengan objek yang ditangani serta tempat lembaga sekolah itu berada. Manajemen yang dapat menyesuaikan diri dengan berbagai situasi dan kondisi disebut manajemen yang fleksibel (pidarta, 2004: 16) ${ }^{5}$. Artinya, manajemen dalam lembaga tersebut tidak kaku, dapat berlangsung dalam kondisi dan situasi yang berbeda-beda.

Manajemen keuangan adalah salah satu bidang administrasi pendidikan yang secara khusus menangani tugas - tugas yang berkaitan dengan pengelolaan keuangan yang dimiliki dan digunakan dalam lembaga pendidikan. Penggunaan uang ditaman kanak - kanak harus dapat dipertanggungjawabkan demi memperlancar pencapaian tujuan pendidikan. 2 hal yang perlu digaris bawahi berkaitan dengan manajemen keuangan TK

1. Manajemen keuangan merupakan keseluruhan proses upaya memperoleh dan penggunaan semua dana.

2. Penggunaan semua dana harus efektif dan efisien

Adapun Tujuan manajemen keuangan dilembaga pendidikan adalah untuk mengatur semua hal - hal terkait dengan keuangan sehingga upaya pemerolehan dana dari berbagai sumber dapat dilakukan dengan sebaik - baiknya. Selain itu tujuan pelaksanaa manajemen keuangan di lembaga pendidikan adalah untuk mengatur semua pemanfaatan dana yang tersedia atau diperoleh dari semua sumber sedangkan prinsip dari manajemen keuangan antara lain.

a. Sumber dana pendidikan di TK tidak sedikit, tidak hanya dari pemerintah atau yayasan yang menaunginya

b. Dana pendidikan yang tersedia harus dimanfaatkan secara efektif dan efisien

c. Semua manajemen keuangan dijaga hendaknya didasarkan pada peraturan perundang - undangan keuangan yang berlaku sehingga dapat dipertanggungjawabkan

d. Pelaksanaan manajemen keuangan di TK merupakan tanggung jawab kepala taman kanak - kanak

Beberapa pendapat ahli diatas, maka dapat disimpulkan secara umum bahawa manajemen merupakan suatu proses pemanfaatan sumber daya manusia melalui kerjasama dengan orang lain untuk tindakan perencanaan, pengorganisasian, penggantian, dan pengawasan

\section{Konsep Dasar Pembiayaan Pendidikan}

Menurut Sumiyanto (2008: 165), "Pembiayaan adalah aktivitas menyalurkan dana yang terkumpul kepada anggota pengguna dana, memilih jenis usaha yang akan

\footnotetext{
${ }^{4}$ Pidarta manajemen pendidikan Indonesia, (Raja Grafindo persada, 2004), hlm. 3.

${ }^{5}$ Pidarta manajemen pembiayaan (Bandung: PT Remaja 2004), hal 16.
} 
dibiayai agar diperoleh jenis usaha yang produktif, menguntungkan dan dikelola oleh anggota yang jujur dan bertanggung jawab". Sementara itu, menurut Keputusan Menteri Negara Koperasi Dan Usaha Kecil Dan Menengah No: 91/Kep/M.KUKMI/IX/2004 tentang Petunjuk Kegiatan Usaha.

Fattah $(2006: 112)^{6}$ mendefinisikan biaya pendidikan sebagai sejumlah uang yang dihasilkan dan dibelanjakan untuk berbagai keperluan penyelenggaraan pendidikan yang mencakup gaji guru, peningkatan kemampuan professional guru, pengadaan sarana ruang belajar, perbaikan ruang belajar, pengadaan prabot/mobiler, pengadaan alat-alat pelajaran, pengadaan buku-buku pelajaran, alat tulis kantor, kegiatan ekstra kurikuler, kegiatan pengelolaan pendidikan, dan supervisi pembinaan pendidikan serta ketatausahaan sekolah.

Secara teoritis konsep konsep biaya dibidang lain mempunyai kesamaan dibidang pendidikan, yaitu lembaga pendidikan dipandang sebagai produsen jasa pendidikan yang menghasilkan keahlian, ketermapilan, ilmu pengetahuan, karkter dan nilai yang dimiliki oleh seorang lulusan. Berdasarkan pengertian ini, pembiayaan pendidikan memiliki cakupan yang luas, yakni semua jenis pengeluaran yang berkenaan dengan penyelenggaraan pendidikan, baik dalam bentuk uang maupun barang dan tenaga.

Berbagai studi diIndonesia telah pula mencoba memperhitungkan biaya pendidikan berdasarkan standar kecukupan. Konsep pendekatan kecukupan menjadi penting karena memasukan berbagai standar kualitas dalam perhitungan pembiayaan pendidikan sehingga perhitungan biaya pendidikan berdasarkan pendekatan kecukupan ditentukan oleh beberapa faktor, diantaranya: (a) Besar kecilnya sebuah institusi pendidikan; (b) Jumlah siswa; (c) Tingkat gaji guru (karena bidang pendidikan dianggap sebagai highly labour intensive); (d) Rasio siswa dibandingkan jumlah guru; (e) Kualifikasi guru; (f) Tingkat pertumbuhan populasi penduduk (khususnya di negara berkembang); (g) Perubahan dari pendapatan (revenue theory of cost).

Sesuai dengan Undang-Undang RI No. 16 Tahun 2001 Tentang, defenisi adalah badan hukum yang terdiri atas kekayaan yang dipisahkan dan diperuntukan untuk mencapai tujuan tertentu dibidang sosial, keagamaan, dan kemanusiaam, yang tidak mempunyai anggota. sebagai salah satu bentul badan hukum adalah sangat penting sekali bagi organisasi islam. Setiap lembaga swadaya masyarakat (LSM) atau Non Goverment Organization (NGO) islam.

Menurut C.S.T. Kansil dan Christine S.T. Kansil, (2000: 198) ${ }^{7}$ atau Stichting (belanda) adalah suatu badan hukum yang melakukan kegiatan dalam bidang sosial. Subekti, menyatakan bahwa adalah badan hukum dibawah pimpinan suatu badan pengurus dengan tujuan sosial dan tujuan tertentu.

Departemen Pendidikan menegaskan bahwa orientasi pengawasan anggaran pada sebelas hal yaitu (1) system pengawasan fungsional, (2) hasil temuan pengawasan harus

\footnotetext{
${ }^{6}$ Fatah, rohadi. Abdul. Rekonstruksi Pendidikan masa depan, (Jakarta; Lista Fariska Putra, 2008), hlm. 56.

${ }^{7}$ C.S.T. Kansil. Otonomi manajemen sekolah, Bandung;Alfa Beta
} 
ditindak lanjuti untuk mendapatkan pemecahan masalah yang dihadapi secara bersama, (3) kegiatan pengawasan hendaknya diarahkan pada bidang strategis, (4) kegiatan pengawasan hendaknya member dampak terhadap penyelesaian masalah dengan konseptual dan menyeluruh, (5) kegiatan pengawasan dilakukan oleh ornag-orang yang memiliki kompetensi teknis, sikap, dedikasi dan integritas pribadi yang baik,(6) akurat artinya informasi tentang kinerja yang dewasa memiliki ketepatan data yang sangat tinggi (7) ketepatan waktu artinya data yang dihasilkan dapat digunakan sesuai dengan saat untuk melakukan perbaikan, (8) obyektif dan komprehensif (9) tidak mengakibatkan pemborosan (10) tindakan dan kegiatan pengawasan bertujuan untuk menyamakan rencana yang telah di buat, (11) kegiatan pengawasan harus mampu mengoreksi dan menilai pelaksanaan pekerjaan sesuai dengan rencana semula.

\section{METODE PENELITIAN}

Pendekatan yang digunakan dalam penelitian ini adalah pendekatan kualitatif, yang lebih menekankan pada pengungkapan makna dan proses dengan latar belakang alami sebagai sumber data langsung. Digunakan pendekatan kualitatif karena adanya kesesuaian antara karakteristik dan ciri-ciri yang cocok, diantaranya instrument utamanya adalah manusia/peneliti itu sendiri, karena peneliti berada langsung di lapangan dalam proses pengumpulan data. Bersifat deskriptif berarti data yang dipaparkan secara lisan dalam bentuk kata dan kalimat, yaitu data tentang pembiayaan pendidikan di MTs Darul Khair Masing Luwuk Banggai

Rancangan penelitian yang digunakan dalam penelitian ini adalah studi kasus. Studi kasus merupakan penelitian yang mendalam tentang individu, satu kelompok, organisasi, suatu program kegiatan, dan sebagainya dalam waktu tertentu. Tujuannya memperoleh gambaran yang utuh dan mendalam dari sebuah entitas. Penggunaan pendekatan kualitatif dalam penelitian ini dengan tujuan dapat menggambarkan fenomena-fenomena atau gejala-gejala yang aktualyang berhubungan dengan pembiayaan MTs Darul Khair Masing Luwuk Banggai termasuk mengenai sumber-sumber pembiayaan, Manajemen anggaran pendapatan pembiayaan, penggunaan anggaran belanja pembiayaan, pertanggungjawaban pembiayaan, dan pengawasan pembiayaan.

\section{HASIL PENELITIAN DAN PEMBAHASAN}

Hasil wawancara yang tentang sumber-sumber pembiayaan pada MTs Darul Khair Masing bahwa sumber pembiayaan merupakan donator atau masyarakat umum yang memberikan sumbangan untuk pembiayaan dalam kegiatan proses belajar mengajar dan merupakan kunci keberhasilan dalam pembelajaran. Selain itu penyelenggaraan pendidikan di Darul ulum bersumber dari donator tetap para orang dan masyarakat umum yang peduli terhadap MTs Darul Khair Masing tersebut. Yang lebih disayangkan adalah tidak adanya perpanjangan tangan dari Pemerintah Pusat maupun daerah.

Adapun bantuan sarana-prasarana dari kementrian Agama cabang Kabupaten Luwuk itu hanya berupa dalam bentuk barang (alat) dan sebagainya tidak dalam bentuk uang. Berdasarkan uraian di atas, ini menunjukan bahwa jumlah anggaran pembiayaan pendidikan MTs Darul Khair Masing dari berbagai sumber masih belum cukup. Terkadang dana yang dimiliki MTs Darul Khair Masing hanya cukup untuk pembelajaran satu semester saja. Nah, untuk menutupi kekurangan yang ada, maka pihak 
MTs Darul Khair Masing mengambil langkah mensiasati anggaran dengan cara cara memprioritaskan kegiatan yang terpenting. Kegiatan terpenting yang dimaksud adalah kegiatan yang mendesak dan sangat dibutuhkan sesuai keperluan tersebut.

Hasil dokumentasi juga menunjukan bahwa MTs Darul Khair Masing dari segi infrastruktur sangat minim, mereka belajar dengan gedung seadanya. Ini dikarenakan keterbatasan dana yang dimiliki ini. Karena, sumber dana yang pasti tidak ada. Semuanya berdasarkan keikhlasan dari masyarakat umum dalam menyumbangkan dana untuk tempat belajar agama tersebut

Hasil wawancara tentang Manajemen anggaran pendapatan pembiayaan pendidikan MTs Darul Khair Masing jelas menunjukan bahwa di MTs Darul Khair Masing dalam hal Manajemen anggaran pendapatan yang ingin dicapai ada programnya. Berdasarkan jangka waktu yang menjadi prioritas. Jangka waktu yang digunakan terdiri atas: jangka pendek dan jangka menengah, sedangkan prioritas jangka panjang tidak ada. Manajemen pendapatan yang ingin di capai pada jangka pendek adalah pada akhir semester berjalan maupun akhir tahunan. Kemudian Manajemen pendapatan jangka menengah biasanya berlangsung pada lima tahun pelajaran. penyusunan anggaran pendapatan pembiayaan pendidikan MTs Darul Khair Masing melibatkan berbagai pihak untuk ikut andil dalam pengambilan keputusan Manajemen pendapatan biaya. Pihakpihak tersebut yakni, masyarakat umum, stekholder, para guru pengajar, bendahara dan sebagainya. Manajemen pendapatan anggaran biasanya dilakukan pada awal pelajaran.

Realisasi Manajemen yang telah dibuat dalam penerimaan anggaran pembiayaan pendidikan di sudah relevansi dengan rencana awal sebelum pelaksanaan pembelajaran. Setiap penyelenggaraan pendidikan dalam hal kaitannya penggunaan anggaran di setiap organisasi sekolah yang pastinya tidak terlepas dari permasalahan dengan pelaksanaannya. Akan tetapi, permasalahan tersebut dicarikan solusinya.

Hasil wawancara yang di dukung dengan dokumentasi tentang bagaimana mengatasi kekurangan dan masalah yang dihadapi di MTs Darul Khair Masing sangatlah bijak. Karena, salah satu strategi yang mampu menyikapi problem yang menjadi kendala di MTs Darul Khair Masing tersebut dengan cara pengeluaran anggaran sesuai dengan Manajemen, di samping itu, kalau pun ada kebutuhan mendesak dan sangat urgen merupakan kebutuhan yang terlebih dahulu disikapi. Tak kalah pentingnya pula partisipasi masyarakat dalam menangani permasalahan yang dihadapi Darul Ulum. Dengan berbagai cara yang dilakukan oleh masyarakat untuk menanggapi kebutuhan tersebut.

Hasil dokumentasi menunjukan bahwa rapat kerja yang melibatkan berbagai pihak dengan pelaku pendidikan untuk menyusun perencaanaan pendapatan pembiayaan pendidikan. Masyarakat sangat antusias dalam rapat kerja tersebut. Koordinasi pimpinan dengan orang tua santri berjalan dengan baik pula

Hasil wawancara tersebut didukung pula hasil observasi tentang penggunaan anggaran pembiayaan pendidikan MTs Darul Khair Masing . Berdasarkan pengamatan yang dilakukan menunjukan bahwa penggunaan anggaran sudah sesuai dengan Manajemen awal yang telah direncanakan dan tepat sasaran. Meskipun ada permasalahan yang dihadapi dalam penggunaannya, tapi hanya sebagian kecil saja. Hasil observasi pula tentang keterlibatan masyarakat dalam berbagai hal untuk mencapai 
penggunaan anggaran yang semaksimal mungkin sangat optimal. Pada tanggal 27 Maret 2015 jam 9 pagi peneliti berada di MTs Darul Khair Masing dan menyaksikan banyak orang tua santri yang menghadiri rapat Manajemen pembiayaan pendidikan MTs Darul Khair Masing .

Terkait dengan pertanggungjawaban sekolah, berikut Hasil wawancara yang bahwa pertanggungjawaban penggunaan anggaran pembiayaan pendidikan di MTs Darul Khair Masing sudah sesuai dengan prosedur dan dibukukan secara resmi berdasarkan aturan resmi. Dengan membuat perincian penggunaan anggaran setiap akhir tahun. Serta pelaksanannya melibatkan banyak pihak, salah satunya adalah masyarakat selaku orang tua santri yang terlibat langsung dalam pelaporan pertanggungjawaban anggaran yang digunakan

Hasil wawancara tersebut bahwa pertanggungjawaban penggunaan anggaran pembiayaan pendidikan di MTs Darul Khair Masing sudah sesuai dengan prosedur dan dibukukan secara resmi berdasarkan aturan resmi. Dengan membuat perincian penggunaan anggaran setiap akhir tahun. Serta pelaksanannya melibatkan banyak pihak, salah satunya adalah masyarakat selaku orang tua santri yang terlibat langsung dalam pelaporan pertanggungjawaban anggaran yang digunakan.

Hasil studi dokumentasi juga menunjukan bahwa antara pengelola dengan para masyarakat sangatlah baik. Hal tersebut dapat dilihat dari pelaporan pertanggungjawaban dari pihak yang mengikutsertakan masyarakat umum yang memiliki kepentingan bersama di MTs Darul Khair Masing tersebut. Pelaporan anggaran juga berdasarkan kwitansi setiap perbelanjaan yang berkaitan dengan kebutuhan MTs Darul Khair Masing . Merupakan hal yang tidak wajar jika pertanggungjawaban anggaran hanya berdasarkan argument-argumen yang tidak didukung dengan bukti fisik. Olehnya itu, setiap pertanggungjawaban apa pun yang berkaitan dengan dana sejatinya berdasarkan dengan bukti yang riil. Serta tidak menyimpang dari batas-batas ketentuan yang berlaku.

Terkait dengan hasil wawancara tentang pengawasan pembiayaan pendidikan MTs Darul Khair Masing dengan informan, bahwa dalam pengawasan pembiayaan pendidikan MTs Darul Khair Masing ditugaskan pada tim khusus yang bertugas mengawasi dan mengotrol keuangan yang diperoleh oleh MTs Darul Khair Masing juga pengeluaran perbelanjaan kebutuhan pokok. Tim tersebut dibentuk dari hasil rapat bersama masyarakat. Dengan tujuan terbentuknya tim pengawas ini agar penggunaan anggaran sesuai dengan prosedurnya. Tim yang terlibat dalam pengawas anggaran adalah masyarakat selaku orang tua santri, Humas, stekholder pondok, dan Pembina santri.

Hasil wawancara tersebut didukung oleh hasil observasi yang dilakukan bahwa pengawasan pembiayaan pendidikan dilakukan oleh tim yang tergabung dalam berbagai pihak baik masyarakat maupun pihak penyelenggara. Tim tersebutlah yang mengawasi keuangan pondok. Namun, ada kendala dalam mengawasi keuangan pondok, letak kesalahannya pada administrasi saja.

Hasil studi dokumentasi juga menunjukan bahwa antara masyarakat dengan pihak terlibat dalam tim pengawas selaku monitoring keuangan pondok tersebut. Ini dapat dilihat dari struktur pengawas yang telah dibuat berdasarkan hasil keputusan rapat bersama. Pengawas yang dibentuk ternyata sangatlah ramping dan tidak terlalu banyak 
anggotanya. Karena sumber dana yang diperoleh juga hanya berdasar pada masyarakat umum yang lebih dikenal dengan swadaya

\section{PENUTUP}

Berdasarkan hasil penelitian dan pembahasan disimpulkan sebagai berikut Sumber-sumber pembiayaan pendidikan MTs Darul Khair Masing Luwuk Banggai bersumber dari donator tetap masyarakat umum, orang tua santri. Tidak ada bantuan pemerintah baik pusat maupun daerah terhadap penyelenggaraan aktivitas belajar di MTs Darul Khair Masing tersebut. Dunatur tetap memberikan bantuan uang setiap bulan dengan jumlah yang tidak menentu akan tetapi sangat membantu dalam kegiatan oprasional. Bantuan masyarakat umum berupa hasil pertanian seperti sayur dan buahbuahan, hal itu diberikan pada setiap selesai panen. Hal ini sangat membantu dalam kebutuhan logistik santri dan para peembinanya yang tinggal di pondok. Kalau orang tua santri memberi bantuan berupa uang dan matrial bangunan untuk keperluan sarana pondok pesantern, semua orang tua santri terlibat dalam bantuan ini walaupun jenis dan bantuannya berbeda antara satu dengan lainnya. Prosedur Manajemen anggaran pendapatan pembiayaan pendidikan MTs Darul Khair Masing sudah dibuat dalam bentuk program pencapaian anggaran pendapatan.

Program-program tersebut berdasarkan jangka waktu yang ditetapkan, diantaranya: Manajemen anggaran pendapatan pembiayaan jangka pendek dan Manajemen anggaran pendapatan jangka menengah. Sedangkan Manajemen anggaran pendapatan pembiayaan jangka panjang tidak ada. Penggunaan anggaran belanja pembiayaan pendidikan MTs Darul Khair Masing sesuai dengan Manajemen awal yang telah dibuat dan disepakati bersama. Pertanggungjawaban pembiayaan pendidikan MTs Darul Khair Masing sudah sesuai dengan Manajemen dan dilaksanakan pada akhir tahun. Jumlah anggaran penggunaannya juga tidak melenceng dari pelaksanaanya. Pelaku penanggungjawab penggunaan anggaran pembiayaan di tersebut adalah bendahara selaku koordinator keuangan. Agar penggunaan anggaran yang digunakan tidak diselewengkan, maka dibuatkan pembukuan untuk setiap transaksi perbelanjaan keperluan. Pengawasan pembiayaan pendidikan MTs Darul Khair Masing ditugaskan pada tim khusus yang bertugas mengawasi dan mengotrol keuangan yang diperoleh oleh MTs Darul Khair Masing juga pengeluaran perbelanjaan kebutuhan pokok. Tim tersebut dibentuk dari hasil rapat bersama masyarakat. Dengan tujuan terbentuknya tim pengawas ini agar penggunaan anggaran sesuai dengan prosedurnya. Tim yang terlibat dalam pengawas anggaran adalah masyarakat selaku orang tua santri, Humas, stekholder pondok, dan Pembina santri.

\section{DAFTAR PUSTAKA}

Arifin, M. 1995. Kafita Selekta Pendidikan islam (Islam dan Umum), Jakarta: Bumi Aksara.

Arikunto, Suharsimi. 1993. Organisa dan Adminis Pendidikan Teknologo dan Kejuruan, Jakarta: Raja Grafindo Persada.

BSNP. 2006. Standar Biaya Pendidikan Biaya Operasi sekolah Dasar. Jakarta: BSNP.

Budianas, Nanang. 2013. Manajemen Anggaran. http://nanangbudianas.blogspot .co.id. Diakses tanggal 30 November 2015. 
Danim, Sudarwan. 2012. Otonomi Manajemen Sekolah, Bandung: Alfa Beta

Fadhli. 2013. Pengertian Pengawasan. https://iamfadhli.wordpress.com/2013 /01/09/39pengertian-pengawasan/. diakses tanggal 20 November 2015.

Fattah, Nanang. 2008. Pembiayaan Pendidikan: Landasan Teori dan Studi Empiris . "Jurnal, Pendidikan Dasar "Nomor: 9 - April 2008.

................., 2012. Standar Pembiayaan Pandidikan, Bandung: PT. Remaj RosdaKarya.

2012. Ekonomi \& Pembiayaan Pendidikan. Bandung: PT Remaja Rosdakarya.

Irawan , Ade. 2004.Mendagangkan Sekolah: Studi Kebijakan Manajemen Berbasis Sekolah di DKI Jakarta. Jakarta: Indonesia Corruption Watch.

Jahari Jaja, Amirulloh Syarbini, 2013. Manajemen Madrasah Teori, Strategi, dan Implementasi. Bandung: Alfa Beta

Jones T. 2007. School Finance: Technique and Social Policy London: Collier Macmillan Pub

Matin, 2014. Manajemen Pembiayaan Pendidikan Konsep dan Aplikasinya. Jakarta: PT Raja Grafindo Persada.

Manap S. 2008. Manajemen Pendidikan. Bahan Ajar. Bengkulu: Program Magister Manajemen Pendidikan, Universitas Bengkulu.

Minarti, S. 2011. Manajemen Sekolah Mengelola Lembaga Pendidikan Secara Mandiri. Jogjakarta: Ar-Ruzz Media

Munir, abdul. 2008. Seni Mengelola Lembaga Pendidikan Islam, Jakarta:Lekdis Nusantara.

Radha Arfiatur, 2013. Sumber Pembiayaan Pendidikan. http://arfiatur.blogspot. co.id/2013/04/e-sumber-biaya-pendidikan.html. diakses tanggal 20 November 2015 .

Riduwan. 2012. Belajar Muda Penelitian untuk Guru-Karyawan dan Peneliti Pemula, Bandung: Alfa Beta

Riduwan, 2013. Metode dan Tekhnik Menyusun Proposal Penelitian, Bandung: Alfa Beta

Riduwan, 2013. Metode dan Tekhnik Menyusun Tesis, Bandung: Alfa Beta

Sagala, H. syaiful. 2012. Administrasi Pendidikan Kontemporer, Bandung: Alfa Beta

Sagala, H. Syaiful, 2013. Memahami Penelitian Kualitatif, Bandung: Alfa Beta.

Sagala, H. Syaiful, 2013. Metode Penelitian Pendidikan Pendekatan Kuantitatif, Kualitatif, dan $R \& D$, Bandung:Alfa Beta

Somantri, 2014. Manajemen Pendidikan. Bandung: PT Penerbit IPB Press

Suandy, Erly. 2003. Manajemen Pajak, Edisi Revisi, Jakarta: Salemba Empat.

Suparlan, 2013. Manajemen Berbasis Sekolah, Jakarta: Bumi Aksara

Suparta, 2006. Undang-undang dan peraturan pemerintah Republik Indonesia,

Jakarta: Direktorat jenderal Pendidikan Islam Departemen Agama Republik Indonesia.

Supriadi Dedi, 2010. Satuan Biaya Pendidikan Dasar dan Menengah. Bandung: PT Remaja Rosdakarya.

Suparlan, 2013. Manjemen berbasis Sekolah, Jakrta : PT Bumi Aksara 